\title{
THE ROLE OF THE ENVIRONMENTAL ARCHAEOLOGIST IN THE STUDY AND RECONSTRUCTION OF CAVE PALAEOCLIMATE
}

\author{
Maria Gkioni
}

\begin{abstract}
Man and environment are engaged in a continuous battle to impose themselves on one another. The results are found in environmental modifications or climatic oscillations and, as far as man is concerned, in the different character of cultural remains. Man responds to environmental changes by migrating or evolving technological innovations, both of which leave important remains that the archaeologist is called on to recognise and interpret during and after an excavation. They both also reflect the sociocultural responses to climatic stress. This paper refers to a specific case study, caves, which housed man and his activities from the very early prehistoric period, and focuses on the importance of interdisciplinary research among all the sciences which are involved in palaeoclimatic reconstruction.
\end{abstract}

Keywords: environmental archaeology, paleoclimate, caves, Greece.

\section{Introduction}

"The earth is at rest, and the moisture about it is evaporated by the sun's rays and the other heat from above and rises upwards: but when the heat which caused it to rise leaves it, some being dispersed into the upper region, some being quenched by rising so high into the air above the earth, the vapour cools and condenses again as a result of the loss of heat and the height and turns from air into water: and having become water falls again onto the earth"l.

"Cold and heat increase and decrease owing to the sun's course, and because of them the different parts of the earth acquire different potentialities; some are able to remain moist up to a certain point and then dry up and become cold again, while others come to life and become moist in their turn. As places become drier the springs necessarily disappear, and when this happens the rivers at first dwindle from their former size and finally dry up"2.

In this way, Aristotle describes what we call today environmental changes. Regardless of whether Aristotle, writing in the middle of the fourth century B.C., was right or wrong in the way he understood the involvement of the climate in environmental changes, this is a valuable text because it is one of man's first efforts to explain his surroundings. It also means that man was always interested in environmental changes and the interaction he

\footnotetext{
${ }^{1}$ Aristotle, METEOROLOGICA, chapter IX, 24-33. English translation by H.D.P. Lee, M.A. 1951 Harvard University Press.

${ }^{2}$ Aristotle, METEOROLOGICA, chapter XIV, 32-35. English translation by H.D.P. Lee, M.A. 1951 Harvard University Press.
} 
had with his environment. Aristotle shows us how the people at this period understood the environment, giving us an idea of the way of thinking at that time. But what about prehistory, where no written texts exist to inform us about human thoughts or reactions? Even though this is the magic of prehistory ${ }^{3}$, it always remains a problem. In that case, the question is not only what we know and what we wish to know about the past, but also what we are able to know. That means that we cannot learn everything about the human past, because no safe way exists to arrive at this conclusion. Thus, everyone who is working on the past must know the questions he can pose and which of them can be answered with the help of modern technology. In the case of prehistory, the only way to reconstruct the human past is through the various archaeological remains from all kinds of archaeological sites, i.e. open sites, caves, rockshelters, etc. In all these places, man spent his life, cooked his meals, slept, found his food, protected his animals, worked, enjoyed himself, exercised, etc. Through his activities, man has been an important factor in changing the local microenvironment and consequently the local climate. Man also tried to adapt his activities to environmental changes. The study of the simultaneous influence that has been exercised between man and nature is thus essential to the reconstruction of the palaeoenvironment and palaeoclimate.

\section{The environmental archaeologist}

For most specialists in the earth sciences, the past is anything that can be related to the earth's evolution. For specialists in the human sciences, the past is anything that can be related to man himself and to his activities. Thus, archaeology traditionally investigated human beings through their osteological remains, or through huge architectural and cultural achievements (Bintliff \& Van Zeist, 1982, Butzer, 1982, Karali \& Gkioni, 2002b). It is only during the last four decades, with the establishment of prehistoric research, that interest has existed in the daily human life of the past, with an effort to place man in his natural environment. That pushed archaeology to show interest in the environment and environmental conditions, resulting in the foundation of a specific part of this discipline, environmental archaeology (Shackley, 1982, Evans \& O'Connor, 1999, Dincauze, 2000). In modern archaeological research, the emphasis of the interpretation has moved from questions such as 'when' and 'how' certain events happened in the past, to the more important 'why' these events happened. The archaeologist thus tries to reconstruct the human past through the reconstruction of human living conditions, using the techniques associated with the earth sciences, thus sharing with the earth scientist a common aim: to obtain as much information as possible from the examined area. The environmental archaeologist tries to find what the role of mankind is as an active factor of environmental change. Moreover, he tries to find the ways that humans used to adapt to environmental changes. Thus, the main interest for an environmental archaeologist is to understand the interaction between man and environment in the past. In this interaction one of the most, if not the only important factor is climate. With its varieties from place to place and from time to time, it was either a friend or an enemy for the human race (Gamble, 1999,

\footnotetext{
3 "The paradox of the archaeological object is that it is real and tactile so that when we hold it, it seems to bring the past close and to allow us to experience another reality. But at the same time, that other reality is distant and unconnected to the present. To experience the past in this way is to experience the thrill of time travel, an archaeological 'tourism'. The closeness of the object which has itself travelled through time leads us to believe we can do the same”, Hodder 1992, 277.
} 
99, 175, 273). Consequently, knowledge of the palaeoclimate is essential for any interpretation given by the environmental archaeologist.

It is always important for an archaeologist to recognise the climatic stress which pushed man in the past to react. Even when we have no data to support the role of the climate in cultural modifications, because they are not as major as a glacial event, for example, we are almost certain that even minor climatic variations can affect a human society. When man lived in a social context, he showed a considerable ability to adapt to both minor and major stresses. In contrast to this, other societies were unable, or showed less ability to adapt. The ability to adapt depends partly on whether and how the examined society had faced climatic changes. The most useful archaeological evidence of climatic change comes not only from characteristic areas of human settlement, but also from areas where people lived in primitive societies or without any social structure, because they used the simplest technology and had the simplest economic structure.

Although this kind of research is an easy way to arrive at an archaeological explanation, there are some questions regarding its accuracy. Firstly, neither an archaeologist nor an earth scientist is capable of establishing precisely when a climatic event happened. It is possible to talk about a few thousand years or at best about centuries. Moreover, the issue exists when one is trying to understand man or societies before or during the Last Glacial Maximum (LGM). During that time, man was not yet able to face serious climatic changes. The more primitive a society was, the more dependent on the environment man was. But after the LGM, when man started being organised in complicated societies, he became able to confront these kinds of problems. By this time, he had managed to protect himself, by building houses and he managed to find his food by growing plants and taming animals. Thus, climatic change was not always a disaster for him. He could now confront it. This fact is very confusing for an archaeologist, and it proves that the explanation of everything though climatic or environmental change is not always accurate ${ }^{4}$. During an excavation, an archaeologist can distinguish a change in the type or colour of the sediment, which can also be seen as a change in the archaeological material. At the same time, he tries to give a possible chronology for the site. The archaeological remains of a site are those of human activities which resist corrosion and abrasion: the artefacts such as stone tools or potsherds. Apart from these, human activity leaves a number of other remains: the ecofacts, such as pollen, bones, seeds, etc. It is not a very easy task to arrive at an accurate chronology for the latter, especially if the examined site has been disturbed (Bintliff et al, 1988). However, if one wants to make a safe chronology for a site, he must have a statistically representative sample in order to eliminate false interpretations. A very useful material for immediate dating is pottery, because apart from the fact that it enables most archaeologists to give a relative date using its typology, pottery is a perfect material for dating by thermoluminescence, because during the firing of the pot the TL signal reduces to zero if the temperature is high enough. Having found the rel-

\footnotetext{
${ }^{4}$ This was also proved by van Andel et al (1990), who showed that, especially for Greece, it was wrong to believe that the changes we observe in the geological context were because of the climatic influence. As he proved, this was due to human actions on the landscape. This is also the reason why environmental archaeology had a great success in northern Europe and America. It was because of its particular environment, which helps the application of its methods, in contrast to the Mediterranean, where there is a particular depositional process due to the climate and the geomorphological processes, which sometimes create considerable problems during the study and makes the results without control.
} 
ative and the absolute date of the site, the archaeologist usually looks at the environmental state of the place with the help of the earth sciences. When he identifies an important environmental event, such as a climatic one or a tectonic one, during his period of interest, he can accept it without checking, or he can try to verify it. Consequently, he relates the findings of his excavation to the event and as a result, he presents the cause of that change (Hodder, 1992). This is the method that archaeology uses to try to explain an event such as the disappearance of a major civilisation, the abandonment of a previously occupied region, the occupation of a virgin region, changes in population size, or the appearance of new types of economies, such as the invention of agriculture and the growing of plants and taming of animals, for example.

\section{The interdisciplinary study}

Exercising archaeology in practice, an archaeologist has to reconstruct the past landscape through stratigraphy (Butzer, 1981, 1982, Hodder, 1999), the local vegetation through plant remains (Renault-Miskovsky, 1991), and the fauna of the examined place through palaeontology (Lowe \& Walker, 1999, Theodorou \& Agiadi, 2001). He will be helped by scientists specialising in dating and climatic studies. However, the archaeologist must also know that there are some factors that can affect or destroy a type of remains. That means that this type of remains may not be present at the site, or that it is difficult, if not impossible, to find some evidence of their existence. In contrast, one might find a great number of another type of remains simply because it was able to resist its natural destruction. That means that the archaeologist must be able to recognise what is real and what looks real. Another characteristic example of the same question is that of sediments in certain places, where physics or chemistry scientists might produce some results regarding their magnetic parameters or the phosphate concentration and reach conclusions for the use of the site. As a result, if these do not comply with the archaeological remains of the site and its spatial analysis, one cannot obtain the correct idea of the examined place. The phosphate for example might be at a high level because of the existence of burials (Hodder, 1999, 108), or because of other human activities. Micromorphological analyses must also be correlated with the archaeological evidence (Woodward \& Golberg, 2001), because they also depend on the human use of the site ${ }^{5}$.

In a theoretically ideal case, the environmental archaeologist would like to reconstruct all the important resources available to a population at any time and place. This indicates a simultaneous study of data coming from other sciences, like palaeontology, stratigraphy, geology, geomorphology, palaeobotany and off course climatology. All these can provide evidence that could have more than one effect on human existence and wealth. In practice, it takes for granted the reconstruction of the past geological and geomorphological landscape through stratigraphy, which will conclude in the knowledge of the site's formation processes (Farrand, 2001). In this case, the archaeologist, in collaboration with earth scientists, must recognise the human presence within the context of the geological evolution of the site under examination. Earth sciences and especially geology play a key role in the archaeological research and study of cave sediments. Moreover, archaeology

${ }^{5}$ For this subject one can also see Hodder $(1999,112)$, where the author explains the micromorphology of thin sections from floors at Catalhöyük, Turkey. 
and geology have some similar study methods, such as stratigraphic laws or the lack of an experimental control. At the same time, they are different sciences, as they ask different questions and show an interest in different time periods (Hodder, 1999, 107-116). Especially with regard to the Mediterranean area, with its limestone environment, the collaboration with specialists on karst study, even if it is rare, is essential. And because of the fact that many of these karstic areas have no soil at all, the only way to study the area is through cave sediments.

The reconstruction of local vegetation is also important. It is not only the knowledge of the quantity of species that counts in archaeological research, but also the way they were involved in the ecology of the examined place (Hansen, 2001). The plant exploitation at a certain site reflects the human role, or how human involvement changes the natural environment all over the world. Past land use and long-term changes in survival strategies can affect the natural environment. Agriculture, land clearance, irrigation, drainage and grazing are some of the ways in which man affected the landform. Therefore, especially for caves and the study of their climate, palynological data from their interior rarely exist. Usually one relies on the data collected from the external environment, mostly from nearby lakes. Especially for the Mediterranean where there are no adequate palaeoecological studies, a lot of effort must be made to reconstruct past environments, often using the results of palynological research (Dincauze, 2000, 343). In addition, macroscopic remains, which are very often found in caves, can be well preserved inside after their deposition (Hansen, 2001). Carbonisation of seeds, fruit, wood, or other plant parts such as stems and roots, is the most common type of preservation in the cave sediment. Their presence is usually due to natural, human or animal activity, and it is not always easy to recognise their origin. In that case, the environmental archaeologist must collaborate with the palaeobotanist, who will study the palynological data, and will help him to reach a conclusion regarding the vegetation history of the site. Moreover, the archaeologist will try to recognise whether the carbonisation was caused by wilful or accidental human action, and if it took place inside the site or in the outside area. Then he will connect these data with the artefacts or different constructions, such as hearths, found at the examined site. The wood analysis, which will help in the understanding of social and cultural practices and preferences, can also help in the reconstruction of the palaeoenvironment and the palaeoecology of a site.

Another problem that the environmental archaeologist has to face during the study of a site, is the interpretation of faunal assemblages and especially these of fossil vertebrates. They are quite often the remains of human or animal food, or the remains of animals which used the place as a nest or den. Especially for caves, it is also possible that some animals entered caves to die, others died during their hibernation, others fell inside through holes or natural traps in the ground over the cave, and yet others were attracted by already existing carcasses in the cave, and were unable to escape after their dinner, in this way adding their bones to the cave assemblage (Theodorou, 2000, 2001). In that case, the environmental archaeologist has to collaborate with the palaeontologist, who will also study the site. The latter will recognise the species and interpret the taphonomic process, while the former will recognise if there are human traces in animal bones and if man was the cause of the faunal presence in the cave (Dincauze, 2000).

Mollusc assemblages, equally very frequent in cave sediments, pose a third problem. If 
the sediments are protected from erosion, they offer a perfect place for the preservation of mollusc assemblages. Once again, it is difficult to understand the meaning of their presence: they could have been brought there by man; they could have been human or animal litter; in the case of caves, they could have been dropped into the cave through holes or fissures during their transportation by birds; they could have been deposited there by sea action, etc. (Karali, 1979). As in the case of faunal study, the collaboration between the environmental archaeologist and the malacologist will conclude which was the cause of the mollusc assemblages present at the site, but also whether man used them for food, jewellery, spoons or for other purposes.

\section{Caves: a particular case study}

As far as caves are concerned, they have a particular interest for the environmental archaeologist because they constitute a unique place of archaeological remains (Gkioni, 2001, 2002). The most important feature about caves is that, because of their specific microenvironment, their sediments usually are not attacked by erosional forces and they can preserve organic materials such as human or vertebrate bones, micromammals and plant remains, coprolites, etc, which cannot be easily preserved in open-air sites. Moreover, caves may preserve some very precious remains such as paintings and human traces (Karali \& Gkioni, 2002a). In addition, the main advantage for archaeological research is that they (unfortunately not always) provide a safe and accurate stratigraphy (Gkioni, 2000). The problem with the caves is that anthropogenic activities can affect their microclimate. A human presence in a cave can, for instance, increase the amounts of $\mathrm{CO}_{2}$ released by human or animal breathing or by the combustion of wood, as man usually used fire, and in this way modify, at least in some instances, the cave's microclimate and the karstification process.

Even in that case, caves prove very useful in archaeological research, especially in that of the environmental archaeologist, because of the fact that man and animals used caves from their earliest appearance on earth. In Greece for example (fig. 1), only from caves can one gain a complete idea about the human presence in the area, and it is only in caves that the three prehistoric periods of Greece, the Palaeolithic, the Mesolithic and the Neolithic, are represented (Gkioni, 2001). The Mesolithic period in particular (8700-7000 BC), is represented only in caves ${ }^{6}$. The study of these caves is a good example of the method that the environmental archaeologist uses to reconstruct the past environment $^{7}$. Five caves out of six are located close to the sea ${ }^{8}$. As in neighbouring Balkan countries (former Yugoslavia and Bulgaria), the hills and mountains, which were preferred by the Upper Palaeolithic man, are now abandoned. Taking as an example Franchthi cave (fig. 2), which contains deposits from the Upper Palaeolithic to the end of the Neolithic period, and which is a stratified, systematically excavated and published

\footnotetext{
${ }^{6}$ The indications of the existence of a surface site on the island of Kythnos, at the site of Maroulas (fig. 1), are still debated. Until the publication of the final report of this excavation, which will conclude the absolute chronologies of the place, the site is not included in Greek Mesolithic sites.

7 "In order to understand the environment one needs to understand cultural variation, and in order to understand cultural patterning one needs to know the environment" (Hodder, 1999, 114).

${ }^{8}$ The five caves are: Grava in Corfu, Cave of Cyclope at Youra near Alonnessos, Franchthi in the southern Argolid, Zaimis in Attika and Ulbrich, also in Argolid. Theopetra in Thessaly is the only cave which is not coastal (fig. 1).
} 


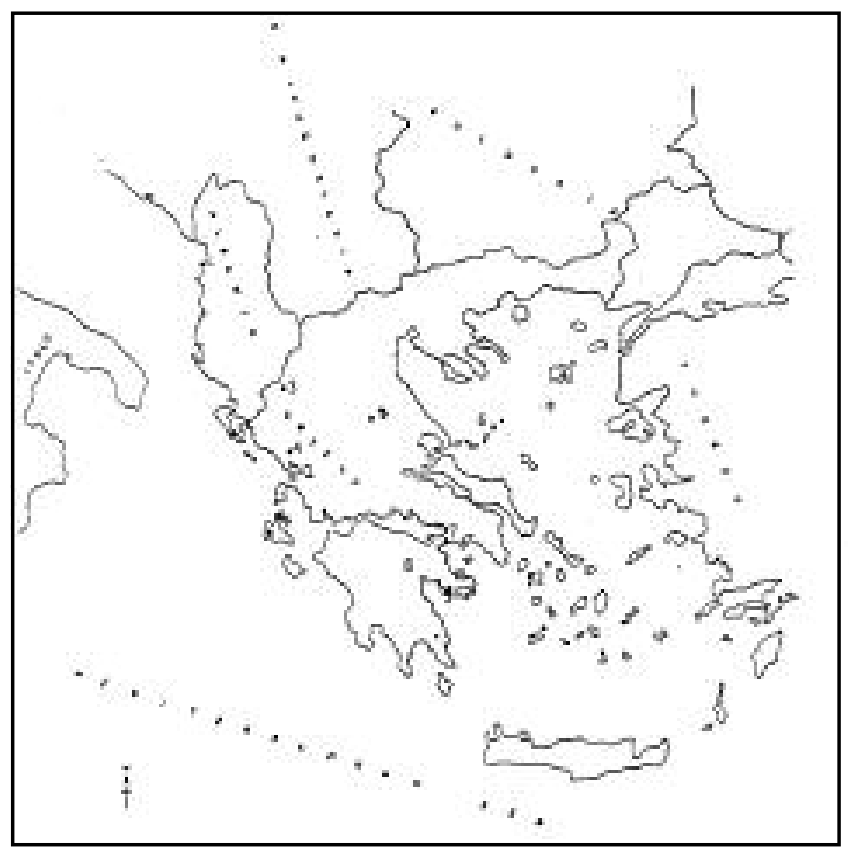

Fig. 1 - Map with the cave sites mentioned in the text: 1 . Franchthi cave, 2. Maroulas, 3. Klithi rockshelter, 4. Asprochaliko rockshelter, 5. Grava cave, 6. Cyclope cave, 7. Zaimis cave, 8. Ulbrich cave, 9 . Theopetra cave.

cave, the faunal remains prove a decline in large game hunting and a simultaneous increase in the exploitation of land and sea resources, such as seeds, snails, seashells, small fish and tuna (Perlès, 2001, 28). The stone tools from the cave also give an indication of modification: the microliths, already known from the Final Palaeolithic, disappear at the beginning of the Holocene and reappear in the same context as the tuna vertebrae (7900-7500 BC). They disappear once again at the end of the Mesolithic (7100-6900 $\mathrm{BC}$ ), at the same time as tuna fishing. It is believed after research into stone tools that their characteristics are due to functional and not to cultural factors. The microliths were used for tuna fishing, which is why they are present in the same context with tuna vertebrae. Moreover, the study of the archaeological material of Franchthi shows that during the Final Palaeolithic and the Mesolithic, man exploited the same species. The difference is in their quantity. During the latter, man exploited more wild plants, molluscs or coastal resources and fewer large animals. Thus, one can easily understand that "most of the differences between the two periods ${ }^{9}$ should probably be attributed to environmental modifications, and to the greater or lesser availability of such primary resources as large game, edible plants and large schools of tuna" (Perlès, 2001, 35).

Through these kinds of research, one can have some first indications of the climate in Greece. At the beginning of the Holocene (9500-8000 BC), the Final Palaeolithic cave sites in Epirus, such as Klithi (fig. 3 \& 4) or Asprochaliko (fig. 5), were abandoned. The diminution of hunting animals due to the expansion of dense forests ${ }^{10}$ is a possible expla-

\footnotetext{
${ }^{9}$ The Final Palaeolithic and the Mesolithic.

${ }^{10}$ The increase of forests in northern Greece is due to the previous period, the Tardiglacial, which was characterised by increased humidity and thus favoured forest growth.
} 


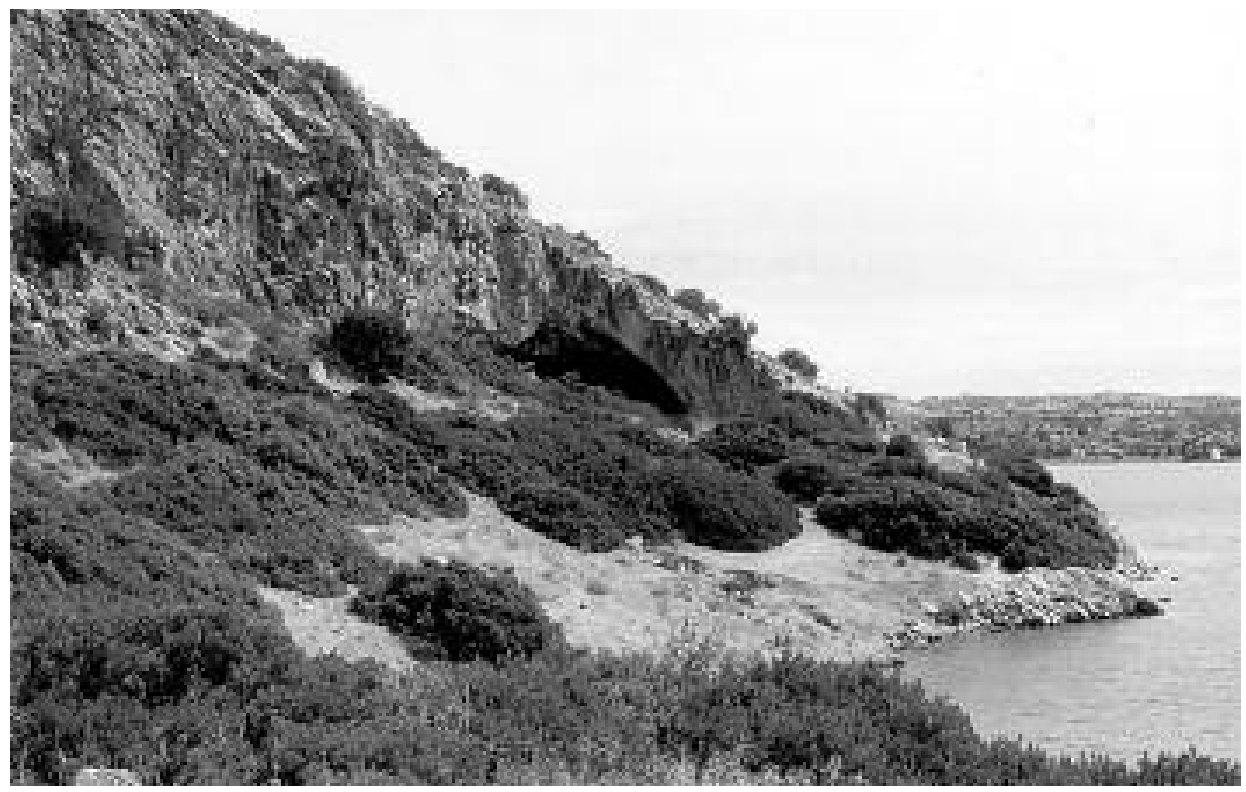

Fig. 2 - General view of the Franchthi Cave.

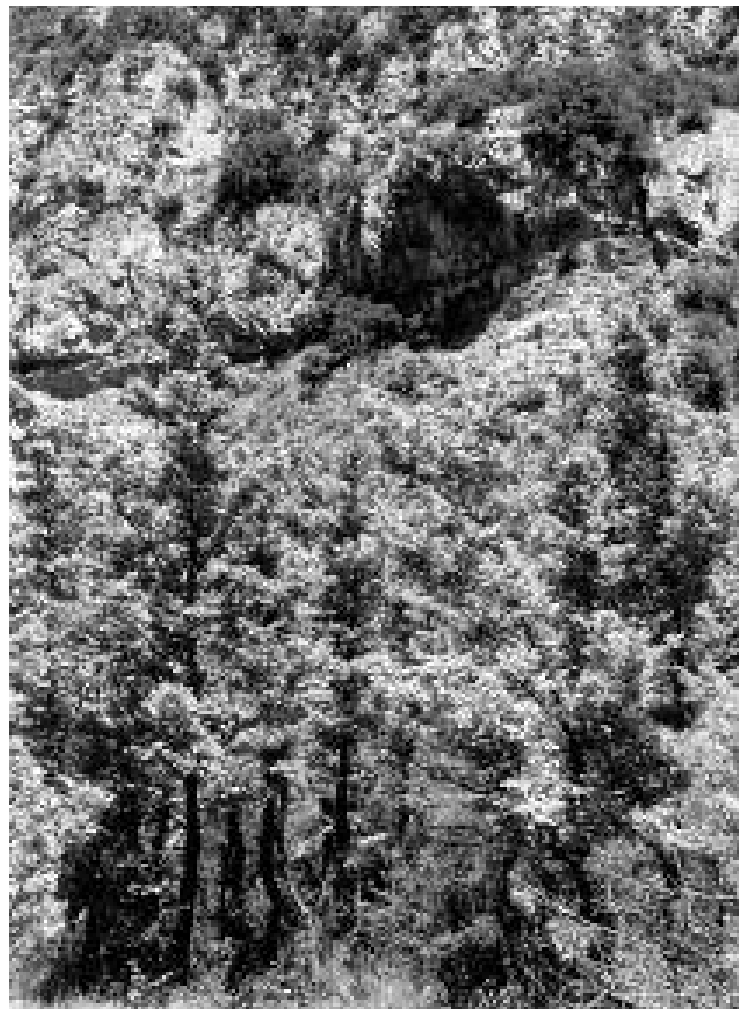

Fig. 3 Northwest view of Klithi. 


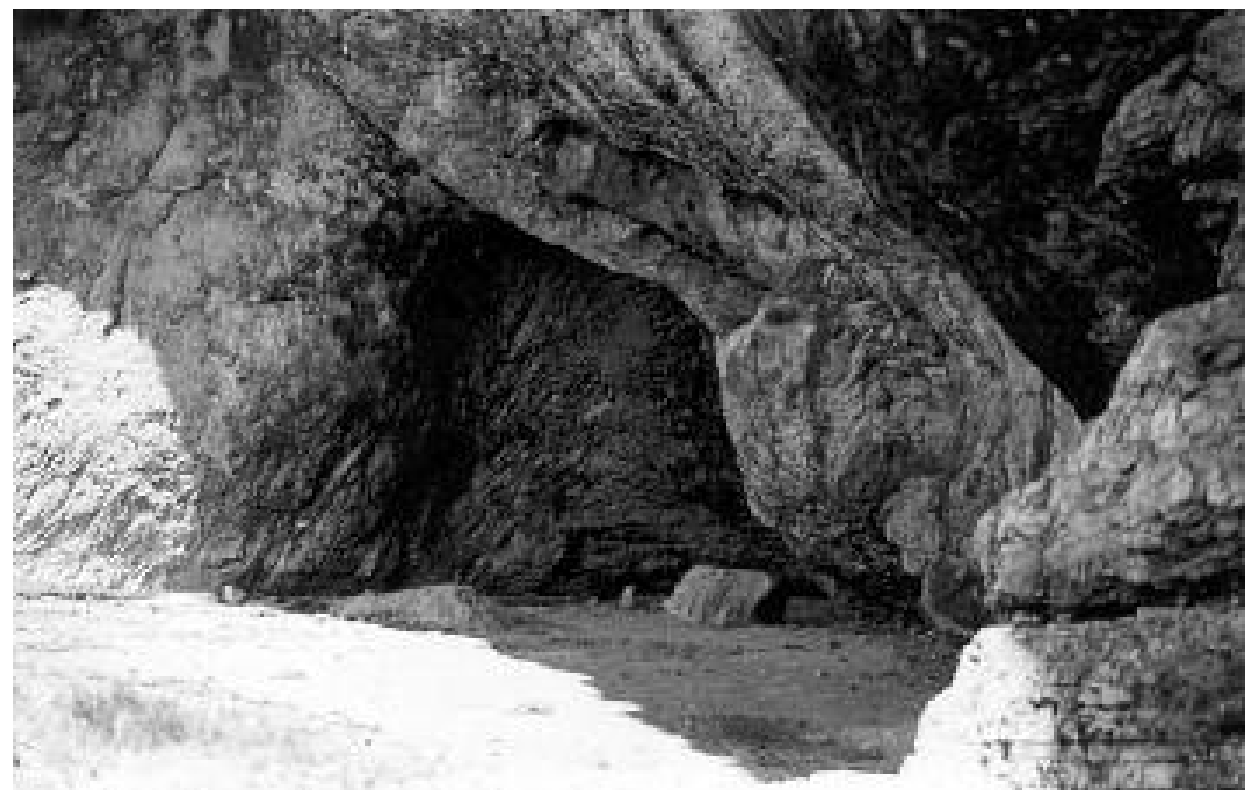

Fig. 4 The Klithi rockshelter.

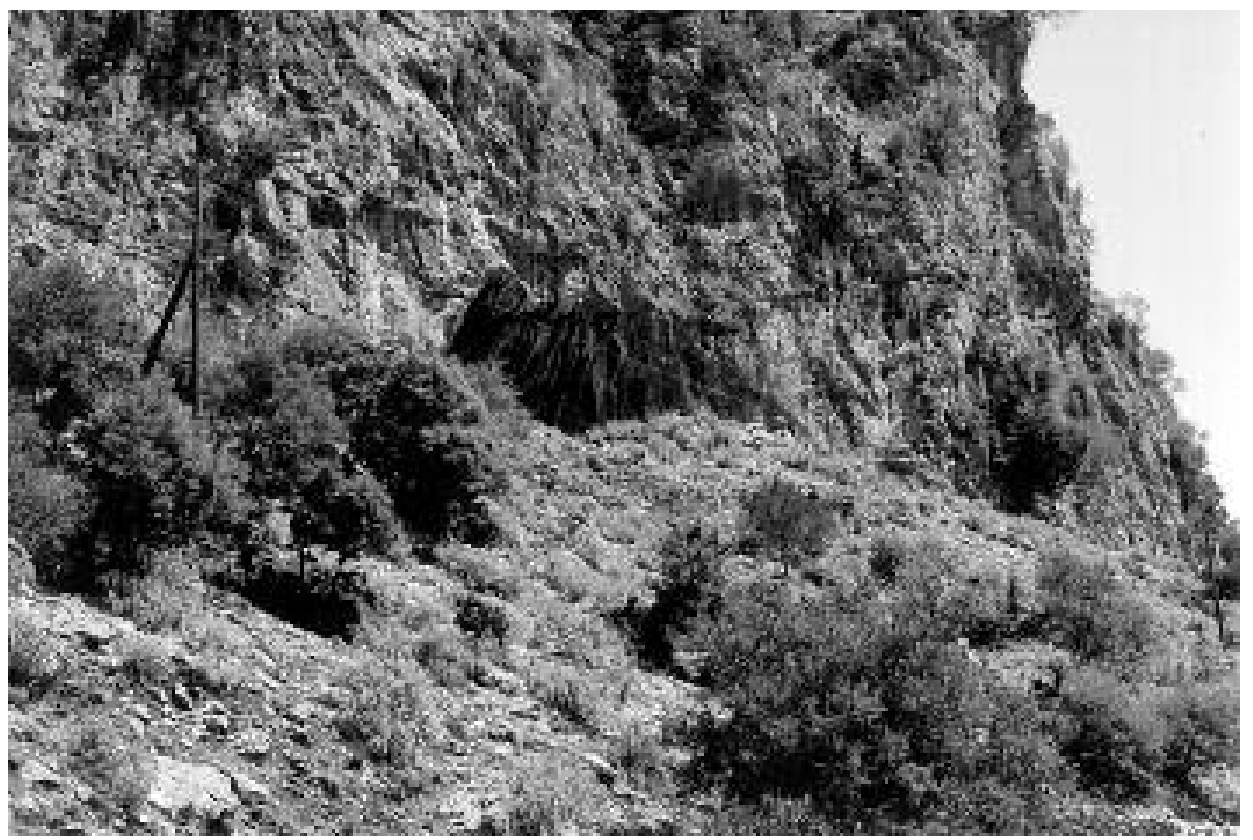

Fig. 5 The Asprocjaliko rockshelter. 
nation of this event. The occupation of Grava cave in Corfu possibly shows a preference for the exploitation of sites in more open forests, or a different environment, also favourable for large game hunting. Franchthi Cave, which has a different surrounding of garrigue but not forest, remained occupied during the whole Mesolithic by the same population, which turned to new available resources. Moreover, because of the fact that these resources were limited, the local populations very quickly adopted agriculture and animal domestication ${ }^{11}$.

\section{Discussion}

When man thinks about climate, he usually means the weather. For most people, climate is precipitation, temperature, air movement and cloud cover. Therefore, climatology as a particular science, studies these effects through their patterns and to what extent they constitute a system. The question for the environmental archaeologist is whether a climatic change or a progressive deterioration in the environment is the result of human interference. Man can affect the environment by burning woods or by overgrazing. This kind of interference can produce a progressive deterioration in the local climate, in the beginning through deforestation, which results in conditions unsuitable for the regeneration of plant cover, and in the end establishing aridity. An archaeologist can give some possible explanation about how man used land in the past (Halstead \& Frederick, 2000). He can give proof of land clearance, drainage or fire. Consequently, the environmental scientist must consider this evidence when he tries to give an explanation based on his own observations (McGhee, 1981). The deterioration in local conditions is largely caused by local effects, which modify topography, temperature and humidity. These effects would include seepage and surface drainage, wind movement and isolation, all of which had consequences for the local climate. Moreover, the environmental archaeologist will suggest the possible modification in human life because of climatic changes (Sherratt, 1997). Man usually develops problems in his blood because of high or low temperatures, etc. The same can be observed in the behaviour of animals or plants. All of them have different reactions according to different climatic modifications. Finally, one can conclude that man can be affected by climatic changes in two ways: in his body and in his economy, especially if these changes are prolonged for many years. In such cases, for instance, a route of communication might be cut off by the development of deserts, marshes, or glaciers. In general, man and large animals are very adaptable and active, so they always find a way to anticipate these changes. The abandonment of settlements and tillage may provide confirmation of changes diagnosed by other means and may throw light on how climate history affects human affairs and economies. Dryness or cold, precipitation or heat could develop or stop production, thus driving a human society to wealth or poverty. Furthermore, there are many climatic changes, which can happen in a small time period. As recently occurred in Western Europe, precipitation caused great damage in just one summer. Even if our social structure and our technology are capable of dealing with the effects of this precipitation, it is certain that it has caused a lot of unsolved problems. One can easily imagine the effects of such precipitation in prehistoric times, when man could deal with the situation in most cases only by migrating. Nor did

${ }^{11}$ This is not the place to discuss the question of whether Greek neolithisation was a local effort or a foreign introduction. 
these effects last for many years. They were short and they perhaps affected only one human generation. Here one can ask whether we are able to find and recognise any remains of this type of climatic change.

\section{Conclusion}

For the reconstruction of past climates, interdisciplinary research is thus indispensable. The archaeologist needs the environmental scientists who will help him understand the context in which human development and behaviour was realised. On the other hand, the environmental sciences need the archaeologist to distinguish the smallest and slightest feature of anthropogenic influences on the earth and the climatic development during the past millennia. The results of the study or the research of each science are considered under different perspectives as they pose different questions. Therefore, for a complete project, the team of scientists must collaborate before the excavation (Bintliff et al, 1988), to determine the method of work and the decisions that must be taken (such as sampling for example). Moreover, the archaeologist will suggest a theoretical approach or a model for the past life in the examined area through ethnoarchaeological or experimental research regarding the occupation of a certain site, and also prove the reality of his model by field observations. The archaeologist uses the results of specialist research of a certain material prepared by an expert, such as a palaeontologist or a palynologist, and prepares one or more environmental models, relying on them to explain a cultural change, a modification of population size, etc ${ }^{12}$.

While reconstructing the palaeoclimate of a site, one must always bears in mind that climate affects not only the resources and their availability, but also living conditions. In the study of the palaeoenvironment and especially of the palaeoclimate, the human dimension cannot be ignored, even if its role in their formation or changes was significantly smaller than it is today. Palaeobotanists, palaeontologists, hydrologists and soil scientists must understand man's influence on local environments if they want to interpret correctly the causes of past climatic changes ${ }^{13}$. Archaeologists, on the other hand, must be able to propose useful suggestions regarding the possible nature of such human impact on local environments.

Finally, the environmental archaeologist does not intend to explain human behaviour or cultural development only through palaeoenvironmental reconstruction. This target would obviously be pointless. The complicated natural world and the human reaction or rather the human response can make clear how difficult is the relation between human societies and nature. The more we know about man's daily life, the better we can understand his choices, his reactions and his thoughts. Besides, the main interest for an archaeologist is man himself, not the precipitation in the past. But the more we learn about both of them, the closer we will come to the answer, which will connect them.

\section{Acknowledgements}

I would like to thank Professor Arrigo Cigna for reading and making valuable comments upon drafts, although all errors and omissions remain my responsibility.

\footnotetext{
12 Palaeodemographers can also help archaeologists in that case, by giving answers to questions regarding population growth or diminution, family size, the number of individuals living in a certain area or site, etc.

13 "Interpretation involve the selection of information according to certain criteria", HODDER, 1999, 67.
} 


\section{References}

Bintliff J.L., van Zeist W. (eds.), 1982 - Palaeoclimates, Palaeoenvironments, and Human Communities in the Eastern Mediterranean Region in Late Prehistory. Oxford, BAR-IS 133.

Bintliff J.L., Davidson D., Grant E., 1988 - Conceptual Issues in Environmental Archaeology. Edinburgh, University Press.

Butzer K.W., 1981 - Cave sediments, Upper Pleistocene stratigraphy and Mousterian facies in Cantabrian Spain. Journal of Archaeological Science 8: 133-183.

Butzer K.W., 1982 - Archaeology as Human Ecology. Cambridge University Press.

Dincauze D., 2000 - Environmental Archaeology: Principles and Practices. Cambridge University Press.

Evans J., O'Connor T., 1999 - Environmental Archaeology. Principles and Methods. Great Britain by Bookcraft, Midsomer Norton, Somerset.

Farrand W., 2001 - Sediments and Stratigraphy in Rockshelters and Caves: A Personal Perspective on Principles and Pragmatics. Geoarchaeology: An International Journal 16: 537-557.

Gamble C., 1999 - The Palaeolithic Societies of Europe. Cambridge University Press.

Gkioni M., 2000 - The caves in prehistoric times. CORPUS, Archaeology - History of civilizations 22: 44-53.

Gkioni M., 2001 - La Reconstitution de la Préhistoire Grecque à travers les trouvailles archéologiques des grottes. Proceedings of the $13^{\text {th }}$ International Congress of Speleology. Brasilia: 144.

Gkioni M., 2002 - Speleology. A not very well known science. CORPUS, Archaeology - History of civilizations 38: 52-61.

Halstead P., Frederick C. (ed), 2000 - Landscape and Land Use in Postglacial Greece. Sheffield Academic Press. Sheffield. England.

Hansen J., 2001 - Macroscopic Plant Remains from Mediterranean Caves and Rockshelters: Avenues of Interpretation. Geoarchaeology: An International Journal 16: 401-432.

Hodder I., 1992 - Theory and practice in archaeology. London and New York.

Hodder I., 1999 - The Archaeological Process. An Introduction. UK. Oxford. Blackwell.

Karali L., 1979 - L'utilisation des mollusques dans la Protohistoire de l'Egée. Thèse du troisième cycle, Université Paris 1.

Karali L., Gkioni M. 2002a, (in press) - Caves, rockshelters and their environment: a theoretical approach of the archaeological perspective. Proceedings of the $8^{\text {th }}$ European Association Archaeologists Annual Meeting. Thessaloniki.

Karali L., Gkioni M., 2002b - The archaeological approach of environment. CORPUS, Archaeology History of civilizations 48: 72-81.

Lowe J.J., Walker M.J.C., 1999 - Reconstructing Quaternary Environments. Second Edition. London: Longman.

McGheen R., 1981 - Archaeological evidence for climatic change during the last 5000 years. In Wigley T.M., Ingram M.J., Farmer G. (eds): Climate and history. Studies in past climates and their impact on Man. Cambridge University Press: 162-177.

Perlès C., 2001 - The Early Neolithic in Greece. Cambridge University Press.

Renault-Miskovsky J. 1991. L'environnement au temps de la Préhistoire. Méthodes et modèles. Editions Masson. Paris.

Shackley M., 1982 - Environmental Archaeology. The Journal of the Society of Antiquaries of London, Oxford University Press 62: 389-390.

Sherratt A., 1997 - Climatic cycles and behavioral revolutions: the emergence of modern humans and 
the beginning of farming. Antiquity 71: 271-287.

Theodorou G., 2000 - New upper quaternary mammal remains from Rethymno Crete (Greece). Bulletin de la Bulletin de la Société Spéléologique de Grèce XXII: 85-94.

Theodorou G., 2001 - Quaternary Continental and Marine Deposits in the Caves of the Aegean Islands, Crete and Coastal Peloponnesus and their Importance for the Understanding Past Environmental Changes. Proceedings of the $13^{\text {th }}$ International Congress of Speleology. Brasilia: 147.

Theodorou G., Agiadi K., 2001 - Observations of the Microstructure of fossil tusks from the Charkadio cave (Tilos, Dodekanese, Greece). Proceedings of the International Congress "The World of Elephants". Rome 2001.

Van Andel, T. et al., 1990 - Landscape stability and destabilisation in the prehistory of Greece: 139157. In: Bottema, Entjes-Nieborg G., van Zeist W. (eds.): Man's role in shaping the eastern Mediterranean landscape. Rotterdam: Balkema

Woeller R., 1982 - Practicing Environmental Archaeology. Methods and Interpretations (0ccasional Papers No 3). London.

Woodward J., Goldberg P., 2001 - The Sedimentary Record in Mediterranean Rockshelter and Caves: Archives of Environmental Change. Geoarchaeology: An International Journal 16: 327-354. 